\title{
Review of different methods and techniques used for flood vulnerability analysis
}

${ }^{1}$ Dilip Kumar and ${ }^{2}$ Rajib Kumar Bhattacharjya

\begin{abstract}
Assessment of vulnerability is the primary objective of flood hazard management. One of the most significant purposes of flood vulnerability appraisal is to make a precise relationship between the theoretical conceptions of flood vulnerability and the ground level management policies. A variety of approaches defined by many researchers to evaluate vulnerability is available, as such a selection of the most suitable methodology is essential for policymakers. The purpose of the present study is to review all the vulnerability methods floating over the research universe and compare their benefits and drawbacks. This study presents a significant examination of more than 250 selected articles published from 1980 to 2020 related to the assessment of vulnerability to determine their competence in the estimation of flood vulnerability. The findings show that statistical methods and weighting allocation were the most extensively used methods to estimate flood vulnerability. Most of the vulnerability assessment methods are centered around the single type of hazard, i.e., flood. As such, the results recommend the necessity for developing a new integrated vulnerability assessment framework applicable to worldwide considering multiple risks.
\end{abstract}

Keywords: Vulnerability; Disaster; Flood; Resilience; Exposure; Risk; Hazards; Techniques.

${ }^{1}$ Research Scholar, Dept. of Civil Eng., Indian Institute of Technology Guwahati, Guwahati 781039, Assam, India. Email: jhadilip27@gmail.com

${ }^{2}$ Professor, Dept. of Civil Eng., Indian Institute of Technology Guwahati, Guwahati 781039, Assam, India. Email: rkbc@iitg.ac.in

1 Introduction

The purpose of the present study is to assess past and current methodologies on different flood vulnerability evaluation strategies. Flooding events are supposed to occur more regularly with destructive nature in the future because of climate change, unplanned rapid urbanization, change in land use pattern, poor watershed management (Blistanova et al. 2016; Commission et al. 2010; Sangati 2009; Villordon 2015). In other words, we can say that many urban areas across the globe are likely to be under serious threat of floods. Effecting control of flood with ensuring the safety of humankind and their belongings with environmental protection is one of the primary responsibilities of concern authorities in flood prone areas (Rimba et al. 2017; 
Shrestha 2008; Temperatures 2011). For obtaining this, identification and reduction of hotspot areas with sever vulnerability is our main target by mapping vulnerability(Beerens et al. 2020). Indeed, flood vulnerability is varying in a spatial and temporal frame; the assessment of vulnerability would be different in different regions around the world (Lee and Choi 2018; Mahmood et al. 2016; Villordon 2015). Different evaluating methods of flood vulnerability have been developed over the last few decades (Liu and Shi 2017; Storch and Zwiers 1999). The present study tried to examine different assessment methods. Before proceeding further, have a look at the destructive nature of flood in the world and India. In the whole world, the human wants to occupy floodplains and forests, placing life and human assets at risk, causing a massive level of vulnerability towards flood (Basheer Ahammed and Pandey 2019; Bhatt and Mall 2015; Diaz-Sarachaga and Jato-Espino 2020). Floods have distorted social support systems, causing extensive stress and disruption to communities and resulting in a massive loss of property, human life, and infrastructure around the world (Lee and Choi 2018; Liu and Shi 2017; Mahmood et al. 2016; Villordon 2015). Even after so much development in technology and science around the world, there is no evidence that the unfortunate trend of extreme flood events will discontinue due to climate change in the future (Diya et al. 2014; Mahmood and Jia 2016). Flooding is considered the most common natural hazard in India, and as a result, affected a higher number of people than any other natural disaster (Bhadra et al. 2009; Parth Sarthi et al. 2015; Rana et al. 2013; Whitehead et al. 2015). As per a report published by National disaster management authority (NDMA) in 2018, India is vulnerable, in diversifying spaces, to a massive number of disasters. More than 58.6 percent of the landmass is prone to earthquakes ranging from moderate to very high intensity (Chakraborty and Joshi 2017; Nisha and Punia 2014). More than 40 million hectares (12.2\%) of the country's land is prone to floods and river erosion, and $68 \%$ of its cultivable area is vulnerable to droughts, along with hilly regions are at risk from landslides and avalanches (Kannan and Ghosh 2011; National Institute of Disaster Management 2012; Pichuka et al. 2017a). As per a study conducted by a committee on disaster management, on average, 75 lakh hectares of land is affected per year, 1600 lives are lost per year, and the damage caused to crops, houses, and public utilities is rupees one thousand eight hundred five crores (Bahinipati 1999; Dimri et al. 2017; Mishra et al. 2013). Due to climate change and rapid urbanization in most of India, the frequency of major floods is more than once in five years, and as a result, floods have also occurred in areas, which were earlier not considered as flood-prone. Fig.1a showing the top ten natural disasters of India based on the casualties, and Fig.1b shows the top ten natural disasters based on economic loss. As per the 
67 and casualties wise (Chakraborty and Joshi 2017; Kumar and Kumar Bhattacharjya 2020a;

68 National Institute of Disaster Management 2012; Pankaj 2018).

69

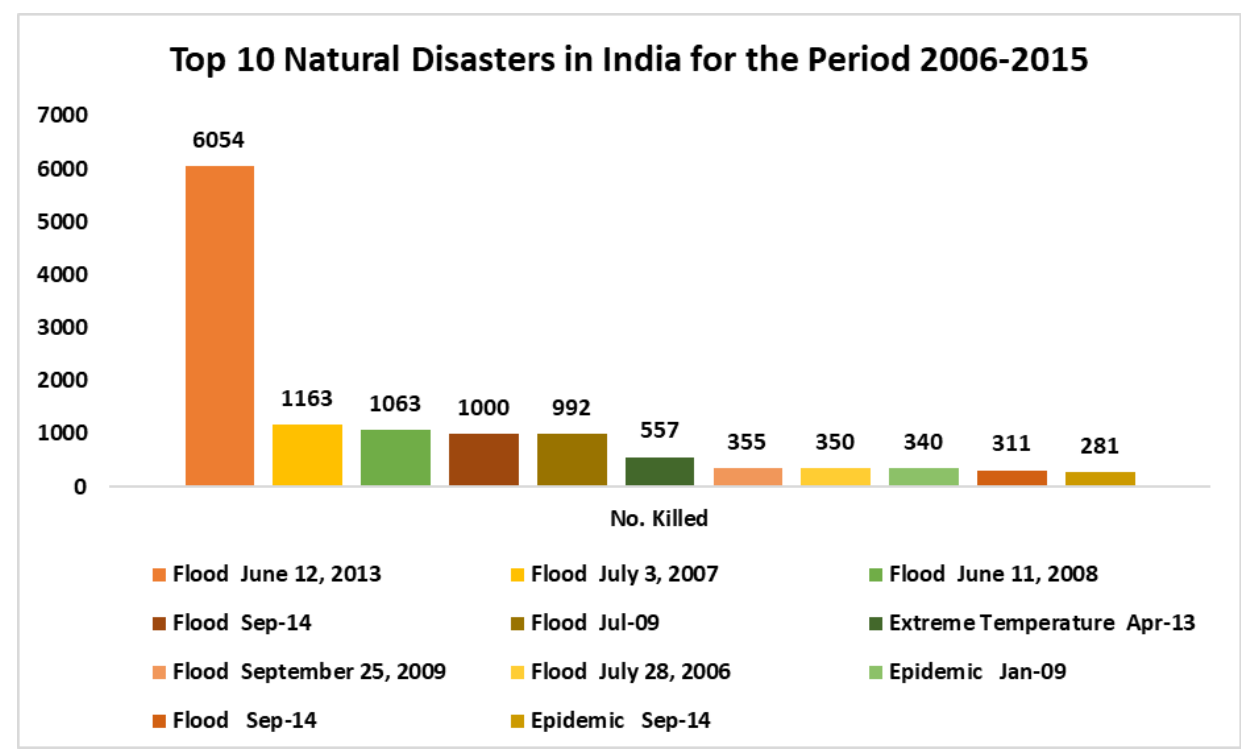

a.

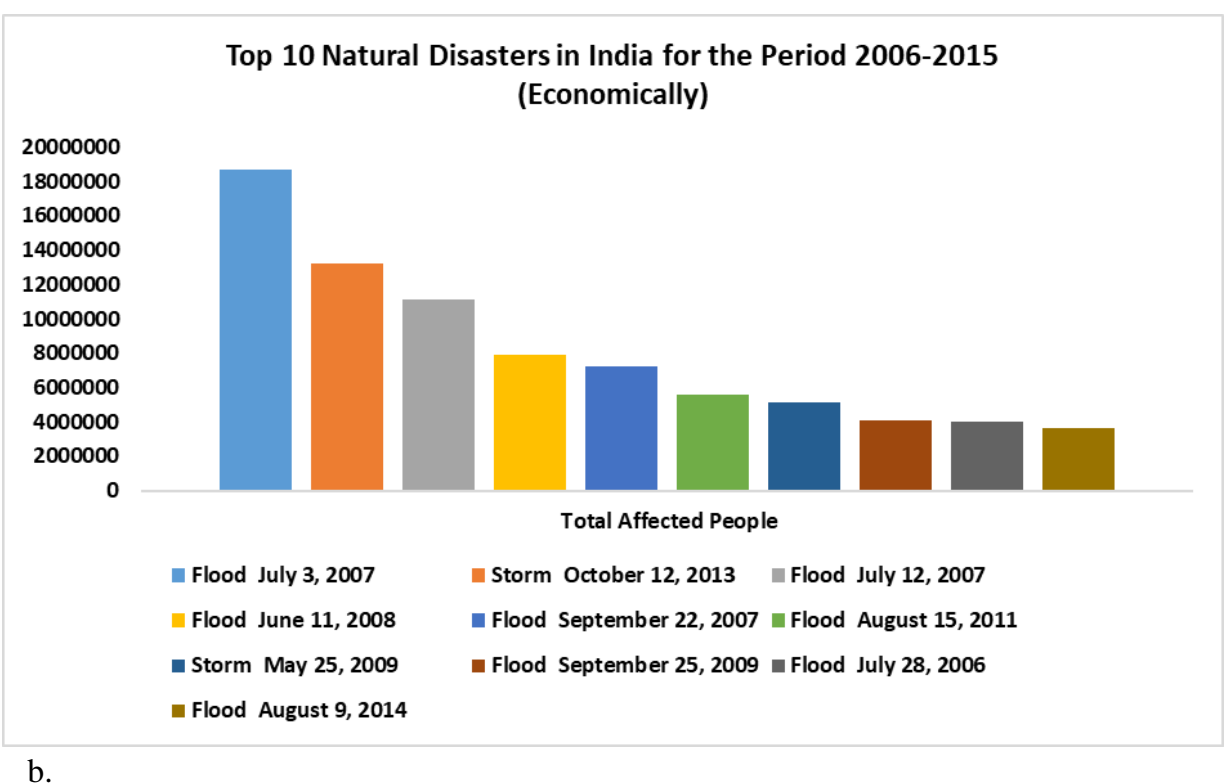

72 Fig:1. Top 10 Natural Disasters in India for the Period 2006-2015 (a) Human loss wise, (b)

73 Economic loss wise 
Table: 1 shows the majority of the disastrous event in India is related to rainfall and discharge as a heat map (Asoka et al. 2017; Chakraborty and Joshi 2017; Kumar and Kumar Bhattacharjya 2020a). The data collected concerning the factors causing disaster in eleven states of India, as shown in Table:1, also verify this. The red colour shows the major death toll and green colour shows the less no of casualties in terms of human death. Where as Table:2, showing the major disaster event round the world in $20^{\text {th }}$ centuray, which describe the flood and earthquake are the major disasterous event occurred in the present centuary in the world. Before starting a discussion on vulnerability, two words, risk, and vulnerability have seemed familiar and confusing. The concept of risk concerning "hazard" and "vulnerability" appears to be the most accepted in floodrisk control, so it is significant to know that "risk" entirely a human subject, the detail definition is explained in Table 3. In the flood risk assessment, generally, floods are classified as (a) Coastal floods, (b) River floods, (c) Flash floods (Damm et al. 2010; Sangati 2009; Shekhar et al. 2015). The primary purpose of flood risk assessment is to reduce the human losses and economic costs to an acceptable level. In other words, flood management does not attempt to eliminate flood risk, but it aims to mitigate them.

Disaster risk assessment consists of (i) Flood preparation reduction measures, i.e., preparation before the disaster (ii) Response steps during the catastrophe and (iii) Recovery (after the disaster) (Chakraborty and Joshi 2017; Management 2014; Pant and Pande 2012; Yalcin and Akyurek 2004). In flood control, there are two main strategies for flood mitigation and security: Structural and non-structural (Ahmed 2006; Damm et al. 2010; Line 1999). The structural measures incorporated all the infrastructure development like levees, dams, or river dike, which can able to change the direction of the river flow, based on collecting, turning, and checking of floods (Singh et al. 2014; Wijaya and Hong 2018). The non-structural measures include various mitigation measures, like educating, recording, prediction and forecasting, assessing measures, land use planning, flood insurance, vulnerability mapping, etc. (Basheer Ahammed and Pandey 2019; Flanagan et al. 2011).

Flood vulnerability assessment is the most significant part of risk analysis in case of any disaster since it can improve our knowledge of the vulnerability(Colburn and Seara 2011; Prasad and Narayanan 2016; Yan and Li 2016). A lot of definition is available to explain the vulnerability around the world, as shown in Table 4 (Blaikie and Cannon 2006; Blistanova et al. 2016; Briguglio 2004; Fatemi et al. 2017; Kumar and Kumar Bhattacharjya 2020a; Studies and Tsakiris n.d.; Villordon 2015; Žurovec et al. 2017). The description of the vulnerability, as shown in Table 3, also explains its temporal and spatial variation nature (Learning n.d.; Rimba et al. 2017; Temperatures 2011; Villordon 2015; Žurovec et al. 2017). Analyzing vulnerability 
is a fundamental component of flood risk management. Historical records reveal that several approaches have been used to assess flood vulnerability (Cardona 2012; Kissi et al. 2015). Thus, it is essential to get several dimensions for a precise comparative assessment of vulnerability. The present study tries to review past studies on flood vulnerability in preview to make a comparable review of different methodologies related to flood-related disasters (Abebe 2014; Alnaimat et al. 2017; Chanawongse. 2011. Pengaruh kompetensi, indepedensi 2014; Management n.d.). Various study around the world has evaluated flood vulnerability using several methods and strategies considering social, socioeconomic, and hydrological aspects such as income, livelihood, infrastructure, age, rainfall, and runoff (Abebe 2014; Analysis 2020; Bereciartua 2015; Vulnerability 2010). Recent studies (2017 onwards) shows the use of spatial and geospatial techniques for estimating and examining the impact of the flood (Diaz-Sarachaga and Jato-Espino 2020; Dottori et al. 2018; Feloni et al. 2020; Pricope et al. 2019a). This article tried to present a comprehensive framework of previous works related to vulnerability, flood hazards, and flood vulnerability. The paper discussed different types of vulnerability, the various indicators of vulnerability, the various methodologies used to calculate the vulnerability index.

\subsection{Definition and concept of vulnerability}

Many scholars, in their own words, defined the term vulnerability (Cardona 2012; Costa et al. 2014; Dottori et al. 2018; Fernandez et al. 2016a; Pricope et al. 2019a; Rimba et al. 2017). Generally, all described the vulnerability as a function of susceptibility, exposure, and, resilience and expressed it as given in Eq. 1 (COSTA and MACHADO 2017; Fernandez et al. 2016b; Godah et al. 2017; Jha et al. 2016; Martini and Loat 2007).

$$
\text { Vulnerability }=\text { Exposure }+ \text { Susceptibility }- \text { Resilience } .
$$

Where, Exposure defines the condition of people, infrastructure, accommodations, production capacities settled in hazard-prone or flood-prone areas. The situation may arise due to the change in climatic parameters or changes in climatic conditions. Susceptibility is defined as the components present within the system, which determine the chances of being harmed at the time of hazards (Brown 2012; Dottori et al. 2018; Kumar and Kumar Bhattacharjya 2020a). The capacity of a social network to counter and overcome any adverse event is called resilience. It includes the strength of the system to absorb impacts, coping with the event as well as postevent adaptive response. In general terms, it helps the system's ability to rearrange, modify, and discover the hazard or any disaster. Resilience can also be understood as the coping capability of a system during flood and restoration ability after the flood. When scanning the 
142 previous study on vulnerability, it was observed that scholars identify the vulnerability in many 143 ways, as shown in Fig.2 (Flanagan et al. 2011; Huang et al. 2005; Pricope et al. 2019b; Seekao and Pharino 2016).

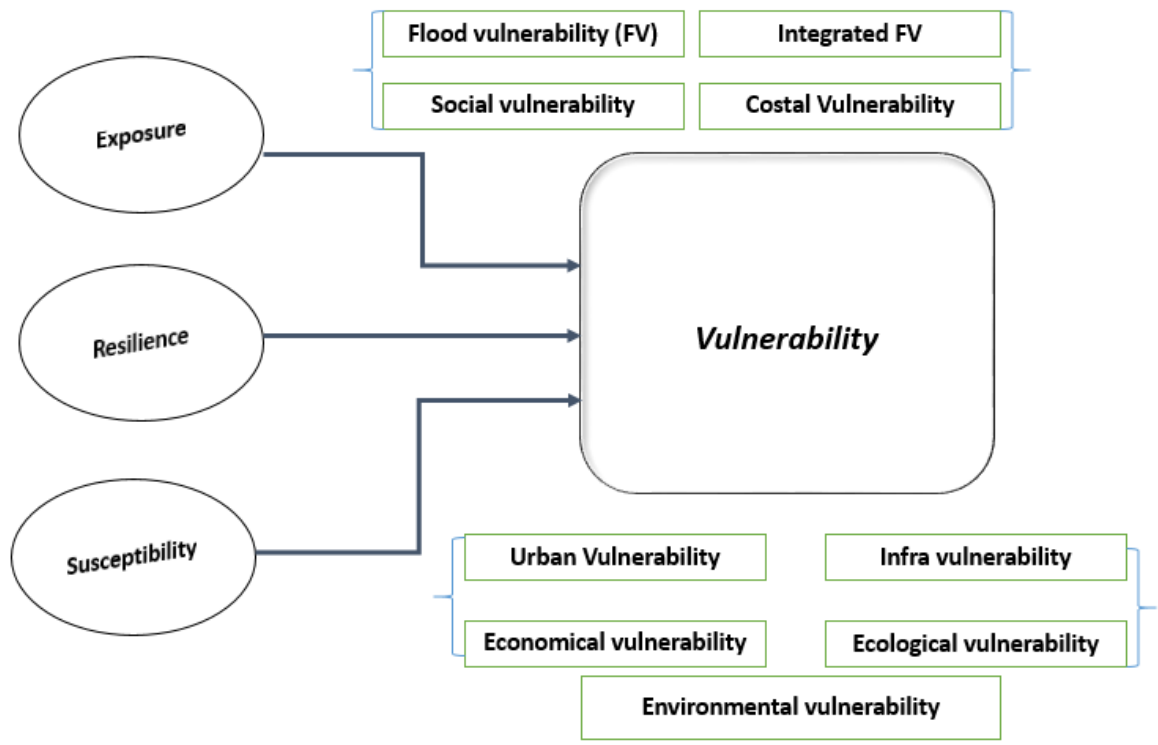

145

Fig. 2: General structure of vulnerability and types

Table 1: Heat map showing the major disaster event in 11 states of India(Commission et al. 2010; Pichuka et al. 2017b; Shukla et al. 2016)

\begin{tabular}{|l|}
\hline Major Disaster Event factor \\
\hline Higher temperature and heat wave \\
\hline Heavy precipitation \\
\hline Flash Flood \\
\hline drainage floods \\
\hline Drought \\
\hline
\end{tabular}

State/\% of major casualties occur

Bihar U P Maharash Rajasthan MP Karnataka Kerala Delhi AP Assam Uttarakhand

\begin{tabular}{rrrrrrrrr|}
\hline 7 & 11 & 4 & 26 & 16 & 9 & 5 & 17 & 8 \\
30 & 27 & 11 & 2 & 21 & 7 & 7 & 19 & 6 \\
\hline & 1 & 9 & 0 & 4 & 2 & 1 & 2 & 3 \\
4 & 6 & 26 & 1 & 3 & 4 & 15 & 11 & 13 \\
12 & 26 & 13 & 19 & 11 & 21 & 7 & 3 & 19 \\
6 & 14 & 9 & 23 & 16 & 19 & 2 & 4 & 18
\end{tabular}

$\begin{array}{rr}2 & \\ 14 & 7 \\ 2 & 31 \\ 4 & 2 \\ 6 & \\ 7 & 2\end{array}$

Water scarcity

Table 2: showing the major disaster event 2round the world in $20^{\text {th }}$ centuray(Diaz-Sarachaga and Jato-Espino 2020; Dottori et al. 2018; Fatemi et al. 2017; Frigerio et al. 2018; Kumar and Kumar Bhattacharjya 2020a; Seekao and Pharino 2016; Villordon 2015)

\begin{tabular}{|c|c|c|c|c|}
\hline Year & Disaster Event & Location & Type & $\begin{array}{c}\text { Death } \\
\text { toll, in } \\
\text { Nos. }\end{array}$ \\
\hline 2001 & $\begin{array}{c}2001 \text { Gujarat } \\
\text { earthquake }\end{array}$ & India & Earthquake & 20085 \\
\hline
\end{tabular}




\begin{tabular}{|c|c|c|c|c|}
\hline 2002 & $\begin{array}{l}2002 \text { Indian heat } \\
\text { wave }\end{array}$ & India & Heat Wave & 1030 \\
\hline 2003 & $\begin{array}{c}2003 \text { European heat } \\
\text { wave }\end{array}$ & $\begin{array}{c}\text { France, Portugal, United Kingdom, } \\
\text { Netherlands, Germany, Spain, Sweden, Italy, } \\
\text { Luxemburg, Ireland }\end{array}$ & Heat Wave & 70000 \\
\hline 2004 & $\begin{array}{l}2004 \text { Indian Ocean } \\
\text { earthquake and } \\
\text { tsunami }\end{array}$ & Indonesia, Sri Lanka, India, Thailand, Somalia & $\begin{array}{c}\text { Earthquake, } \\
\text { Tsunami }\end{array}$ & 227898 \\
\hline 2005 & $\begin{array}{l}2005 \text { Kashmir } \\
\text { earthquake }\end{array}$ & India, Pakistan & Earthquake & 87351 \\
\hline 2006 & $\begin{array}{c}2006 \text { Yogyakarta } \\
\text { earthquake }\end{array}$ & Indonesia & Earthquake & 5782 \\
\hline 2007 & Cyclone Sidr & Bangladesh, India & $\begin{array}{l}\text { Tropical } \\
\text { cyclone }\end{array}$ & 15000 \\
\hline 2008 & Cyclone Nargis & Myanmar & $\begin{array}{l}\text { Tropical } \\
\text { cyclone }\end{array}$ & 138373 \\
\hline 2009 & $\begin{array}{l}2009 \text { Sumatra } \\
\text { earthquake }\end{array}$ & Indonesia & Earthquake & 1115 \\
\hline 2010 & $\begin{array}{l}2010 \text { Haiti } \\
\text { earthquake }\end{array}$ & Haiti & Earthquake & 316000 \\
\hline 2011 & $\begin{array}{l}2011 \text { Tōhoku } \\
\text { earthquake and } \\
\text { tsunami }\end{array}$ & Japan & $\begin{array}{c}\text { Earthquake, } \\
\text { Tsunami }\end{array}$ & 15897 \\
\hline 2012 & Typhoon Bopha & Philippines & $\begin{array}{l}\text { Tropical } \\
\text { cyclone }\end{array}$ & 1901 \\
\hline 2013 & Typhoon Haiyan & Philippines, Vietnam, China & $\begin{array}{l}\text { Tropical } \\
\text { cyclone }\end{array}$ & 6340 \\
\hline 2014 & $\begin{array}{l}2014 \text { Afghanistan } \\
\text { floods }\end{array}$ & Afghanistan & Flood & 26650 \\
\hline 2015 & $\begin{array}{l}2015 \text { Nepal } \\
\text { earthquake }\end{array}$ & Nepal, India & Earthquake & 8964 \\
\hline 2016 & $\begin{array}{l}2016 \text { Ecuador } \\
\text { earthquake }\end{array}$ & Ecuador & Earthquake & 676 \\
\hline
\end{tabular}




\begin{tabular}{|c|c|c|c|c|}
\hline 2017 & Hurricane Maria & Puerto Rico, Dominica & $\begin{array}{c}\text { Tropical } \\
\text { cyclone }\end{array}$ & 3059 \\
\hline 2018 & $\begin{array}{c}2018 \text { Sulawesi } \\
\text { earthquake and } \\
\text { tsunami }\end{array}$ & Indonesia & $\begin{array}{c}\text { Earthquake, } \\
\text { Tsunami }\end{array}$ & 4340 \\
\hline 2019 & Cyclone Idai & Mozambique, Zimbabwe, Malawi & $\begin{array}{c}\text { Tropical } \\
\text { cyclone }\end{array}$ & 1303 \\
\hline 2020 & $\begin{array}{c}\text { 2020 East Africa } \\
\text { floods }\end{array}$ & $\begin{array}{c}\text { Rwanda, Kenya, Somalia, Burundi, Ethiopia, } \\
\text { Uganda, Democratic Republic of the Congo, } \\
\text { Djibouti }\end{array}$ & Flood & 453 \\
\hline
\end{tabular}

154

155

156

157

158

159

160 Table 4: A review of the concept of vulnerability around the world (Basheer Ahammed and

161 Pandey 2019; Blistanova et al. 2016; Chinnasamy et al. 2015; Dhami and Pandey 2013;

162 Fernandez et al. 2016b; Gebreyes and Theodory 2018; Kumar and Kumar Bhattacharjya

163 2020b; Mujumdar 2011; Nisha and Punia 2014; Ojha et al. 2010)

So, finally we have to understatnd the differences between risk, disaster and vulnerability as shown in Table:3.

Table:3 Different terms related to hazard and vulnerability(Kumar and Kumar Bhattacharjya 2020a).

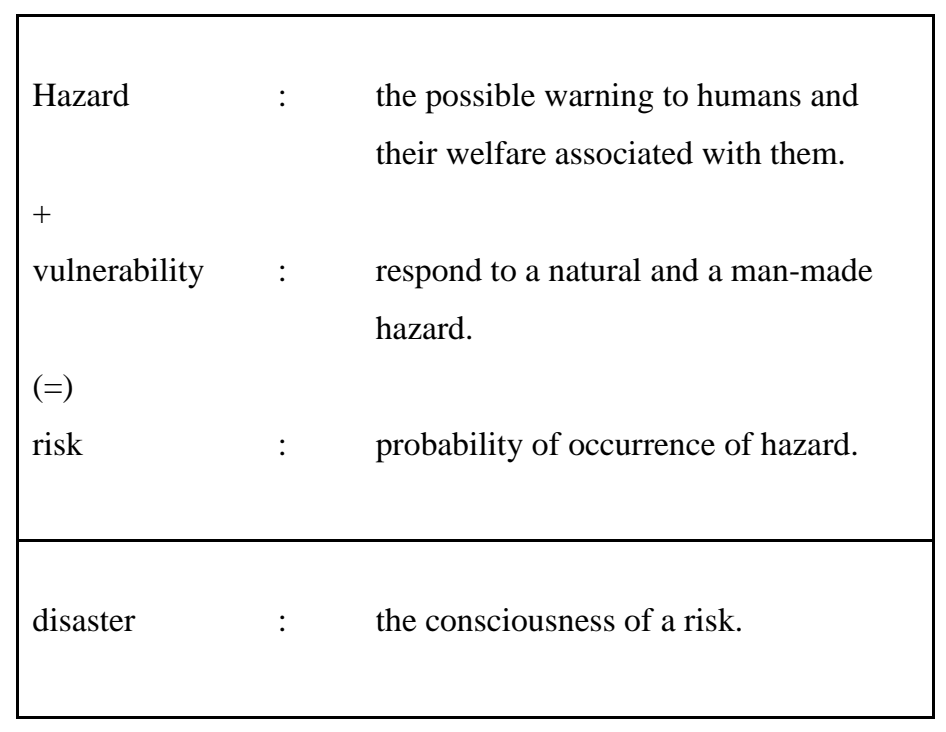




\begin{tabular}{|c|c|}
\hline Source & Definition \\
\hline Kates (1971) & $\begin{array}{l}\text { define vulnerability as a decision model to decide how people } \\
\text { understand hazards. }\end{array}$ \\
\hline United Nations (1982) & $\begin{array}{l}\text { Vulnerability is a level of damage to particular objects at flood risk } \\
\text { with a specified amount and presents on a scale from } 0 \text { to } 1 \text { (no } \\
\text { damage to full loss). }\end{array}$ \\
\hline Laska, 1990 & $\begin{array}{l}\text { define vulnerability in terms of psychosocial impact and } \\
\text { organizational and community impacts on society. }\end{array}$ \\
\hline Blaikie et al., 1994 & $\begin{array}{l}\text { define vulnerability as attributes of a person or group in terms of } \\
\text { their potential to intercept, cope with, resist, and recover from the } \\
\text { impact of a hazard }\end{array}$ \\
\hline $\begin{array}{l}\text { Menoni and Pergalani } \\
\text { (1996) }\end{array}$ & $\begin{array}{l}\text { Vulnerability is damaged goods, people, buildings, infrastructures, } \\
\text { and activities in hazard conditions. }\end{array}$ \\
\hline Mileti, 1999 & $\begin{array}{l}\text { Vulnerability is the measure of the potential to weather, combat, } \\
\text { or recover from the influences of a hazard in the long term as well } \\
\text { as in the short term }\end{array}$ \\
\hline Zaman, 1999 & $\begin{array}{l}\text { Vulnerability indicates the social and economic aspects of a } \\
\text { person, a household, or a group in terms of their capacity to cope } \\
\text { with and to recover from the impacts of disaster }\end{array}$ \\
\hline $\begin{array}{l}\text { Buckle and Smale, } \\
2000\end{array}$ & $\begin{array}{l}\text { define vulnerability as the measure of susceptibility and resilience } \\
\text { of the inhabitants and their corresponding environment to hazards }\end{array}$ \\
\hline UNDP (2004) & $\begin{array}{l}\text { define vulnerability as a state which is influenced by physical, } \\
\text { social, economic, and environmental circumstances that raise the } \\
\text { susceptibility of a community to the hazard. }\end{array}$ \\
\hline Birkmann (2006) & $\begin{array}{l}\text { defined vulnerability as an indicator, which shows the relationship } \\
\text { between the physical, economic, and social contact to the disaster } \\
\text { with the area of interest. }\end{array}$ \\
\hline Persson et al. (2007) & $\begin{array}{l}\text { defined vulnerability as the representation of the physical, } \\
\text { economic, political, or social susceptibility of a community } \\
\text { towards destruction }\end{array}$ \\
\hline UNISDR (2009) & $\begin{array}{l}\text { defines vulnerability as the possibility of harmful outcomes in } \\
\text { terms of deaths, injuries, property, livelihoods, or environment }\end{array}$ \\
\hline
\end{tabular}




\begin{tabular}{|c|c|}
\hline Source & Definition \\
\hline & $\begin{array}{l}\text { damaged occurring from interactions between natural or human- } \\
\text { induced hazards and unsafe conditions. }\end{array}$ \\
\hline Balica (2010) & $\begin{array}{l}\text { Vulnerability is defined with the relationship between exposure, } \\
\text { susceptibility, and resilience of society in case of disaster }\end{array}$ \\
\hline Paulo F. (2016) & $\begin{array}{l}\text { Define vulnerability as a large number of variables into a few } \\
\text { uncorrelated factors representing the social, economic, physical } \\
\text { and environmental dimensions. }\end{array}$ \\
\hline $\begin{array}{l}\text { Skougaard } \\
\text { Kaspersen (2017) }\end{array}$ & $\begin{array}{l}\text { define vulnerability as multidimensional term considering social, } \\
\text { economic, and hydrological components of any state during risk. }\end{array}$ \\
\hline Seok Lee (2018) & $\begin{array}{l}\text { define vulnerability as an integrated framework consists of } \\
\text { exposure, sensitivity, and coping capacity to evaluate the degree } \\
\text { of damage. }\end{array}$ \\
\hline Million G. (2018) & $\begin{array}{l}\text { They summarize vulnerability as 'climate hazard risk setting', } \\
\text { 'subsistence risk setting', 'population increase risk setting', 'state } \\
\text { policy failure risk setting', 'market volatility risk setting', and } \\
\text { 'supernatural risk setting. }\end{array}$ \\
\hline Kumar D. (2020) & $\begin{array}{l}\text { Define vulnerability as a tool of flood hazard management } \\
\text { considering it's multidimensional approach. }\end{array}$ \\
\hline
\end{tabular}

\section{Various dimensions of flood vulnerability}

As discussed earlier, the vulnerability is a multidimensional factor, measuring the effect of the disaster from the local to the community level. Since it covered a large area, the vulnerability classification should be known very well to understand the effect in different regions like costal, infra, flood, etc(Xiao et al. 2020). The different vulnerability classification is discussed below.

\subsection{Social vulnerability}

172 The social vulnerability evaluation concentrates on features of potential weaknesses capacities

173 of the human population(Tan et al. 2020). Many scientists have evaluated social vulnerability

174 and severe issues connected with them. The conditions where people and their different social-

175 cultural groups accommodate them to climate change are an integral part of social adaptability 
and resilience. Social vulnerability directly opposes the prosperity of resources and associated with the susceptibility of the different social communities in terms of shortage of income, inaccessibility of resources, and heading to social and economic crises. Singh et al. (2014) attempted to estimate the flood vulnerability among lower-income people, considering health, wealth, and environmental factors of the society (Fatemi et al. 2017; Kumar and Kumar Bhattacharjya 2020a; Rodrigo 2016; Singh et al. 2014).

\subsection{Coastal Vulnerability}

Coastal regions are considered as central systems for global sustainability, defined as passage areas linking land and sea (Costa et al. 2014; COSTA and MACHADO 2017). Coastal areas got attention because of various uses, like high productivity of the ecosystem, waste disposal, tourism, carrying, and many more. Due to climate change, human interference and increased population density around coastal areas caused the vulnerability of these areas such as sea-level rise, coastal erosion, frequent extreme events, and saltwater encroachment.

\subsection{Urban Vulnerability}

Due to rapid urbanization, change in land use, uncontrolled population growth, and lack of proper drainage systems, urban vulnerability acts as a severe challenge to obtaining sustainable growth (Barroca et al. 2006; Birhanu et al. 2016; Temperatures 2011; Villordon 2015). In a developing country like India and China, due to the complexity of towns, a lot of studies have focused on various characteristics of urban vulnerability for both urbanization quality development and sustainable growth (Diaz-Sarachaga and Jato-Espino 2020; Li and Matthew 1990; Prasad and Narayanan 2016).

\subsection{Infra vulnerability}

Electricity distribution, communication networks, and IT infrastructure are all part of the infrastructure. Human society is entirely dependent on these. All these sectors are co-related with each other(Nojang and Jensen 2020). Failure in one system can cause failures in other systems, may lead to severe infra vulnerability scenario (Len et al. 2018; Nasiri et al. 2019).

\subsection{Flood vulnerability and Integrated Flood vulnerability} The Integrated Flood Vulnerability Index (IFVI) determines which areas are most vulnerable to flooding and should be considered in the future redevelopment (Coninx and Bachus 2007; Huang et al. 2005; Iqbal et al. 2017; Kaspersen and Halsn 2017; Kumar and Kumar 
210 Bhattacharjya 2020a; Sebald 2010). IFVI works like a connection between the general

211 understandings of flood vulnerability and the daily management process. Flood hazard 212 management is a multidimensional approach, and it involves several disciplines such as 213 hydrology, water resource management, economics, statistics, demographic studies, 214 government policy, and planning(Peters and Kelman 2020). The studies considering all these

215 factors to evaluate the effect of flood for the present as well as future scenarios, are under the 216 preview of IFVI.

\subsection{Economic vulnerability}

219 Any disaster not only disturbs the livelihood but also hampers the economic growth of a state 220 and the corresponding society. Infrastructural losses are linked with floods, cause large-scale financial damage, considered as economic vulnerability. Briguglio (2004) have developed a map using GIS of an industrial hotspot in South Holland, which is more vulnerable to flood,

223 mainly due to dense population and diverse nature of economic activities (Adger 1998;

224 Behanzin et al. 2016; Briguglio 2004; Nisha and Punia 2014; Rodrigo 2016).

\subsection{Ecological vulnerability}

227 Along with massive destruction, Floods are also associated with carrying a lot of debris along with them, which cause significant loss to the environment. Damm et al. (2010) highlighted vulnerability to flooding, cyclone, and climate change (Antwi et al. 2015; Damm et al. 2010; Gebreyes and Theodory 2018). The ecological view is one of the critical components of vulnerability. They proposed that sustainability, functionality, and adaptation are essential parameters for evaluating ecological vulnerability. Adger and Brown (2012), in another study, found climate change creates a significant threat to adaptation leading to social, economic, and environmental susceptibility (Brown 2012; Gebreyes and Theodory 2018).

\subsection{Environmental vulnerability}

237 Due to the global warming, rapid deforestation, and sea level change draw the most attention, but many other terrestrial and extra-terrestrial environmental threats like an increase in temperature, uneven distribution of rainfall need to be considered as well (COSTA and

240 MACHADO 2017; Kaly et al. 2005; Ologunorisa 2004; Sapkota et al. 2013; Teng et al. 2017). 
For performing the analysis on several works based on flood vulnerability, various studies were chosen from different research journals at a global level. The systematic approach of these selections is shown in Fig.3 (Ayala et al. 2020; BELL 1980; Blistanova et al. 2016; DiazSarachaga and Jato-Espino 2020; Khajehei et al. 2020; Park et al. 2015; Prasad and Narayanan 2016; Rufat et al. 2015a; Teng et al. 2017; Žurovec et al. 2017). A time period, i.e., 1980-2020, is analyzed for reviewing previously published research works. As such, a total of 250 papers, based on different aspects of vulnerability has been collected and examined.

\subsection{Keyword review}

A table of keywords arranged from previous studies and a total of 25 keywords, which are mostly used, were classified along with their frequency of utilization (Table 5) (Ahmed 2006; Antwi et al. 2015; Banyouko et al. 2017; Chakraborty and Joshi 2017; Costa et al. 2014; Dottori et al. 2018; Fatemi et al. 2017; Flanagan et al. 2011; Kulatunga et al. 2016; Learning n.d.; Pant and Pande 2012; Rahman 2017; Shrestha 2008; Singh et al. 2014; Yalcin and Akyurek 2004). The suggested keywords are linked with classifications for vulnerability and flood-related aspects. All journals included in the review process were Scopus-indexed. The table of keywords is made based on various reviewing studies and expressed graphically. Summary of keyword applied in multiple works supported in evaluating the action focused in the area of flood vulnerability analysis. These keywords were involved in different techniques and procedures used in earlier efforts for vulnerability analysis. 


\begin{tabular}{|c|c|}
\hline Keywords & Frequency \\
\hline Flood & \begin{tabular}{|r|}
83 \\
\end{tabular} \\
\hline Vulnerability & 84 \\
\hline Risk & 79 \\
\hline Disaster & 80 \\
\hline Flood & 74 \\
\hline Climate change & 29 \\
\hline Hazard & 39 \\
\hline GIS & 61 \\
\hline Mapping & 74 \\
\hline Integrated flood vulnerability & 2 \\
\hline flood vulnerability & 85 \\
\hline Flash flood & 69 \\
\hline Flood management & 61 \\
\hline Flood Analysis & 66 \\
\hline indicators & 78 \\
\hline Social vulnerability & 24 \\
\hline Flood risk & 59 \\
\hline Flood vulnerability assessment & 21 \\
\hline Flood index & 19 \\
\hline Exposure & 78 \\
\hline Resilience & 78 \\
\hline Susceptibility & 79 \\
\hline Urbanization & 67 \\
\hline Potential damage & 10 \\
\hline River flooding & 12 \\
\hline
\end{tabular}

270 As discussed earlier, vulnerability is considered as the main component of natural disasters. A

271 list of several attempts on flood vulnerability study was explained in Table 4. The paper

272 selected in the present research around the world, country-wise, is shown in Fig. 4. The mostly

273 papers were selected from Asia region, which depend upon the volume of paper

274 published(Banyouko et al. 2017; Basheer Ahammed and Pandey 2019; Damm et al. 2010;

275 Dickin et al. 2013; Ghani et al. 2012; Huang et al. 2005; Liu and Shi 2017; Mahmood and

276 Babel 2014; Nazeer and Bork 2019). 


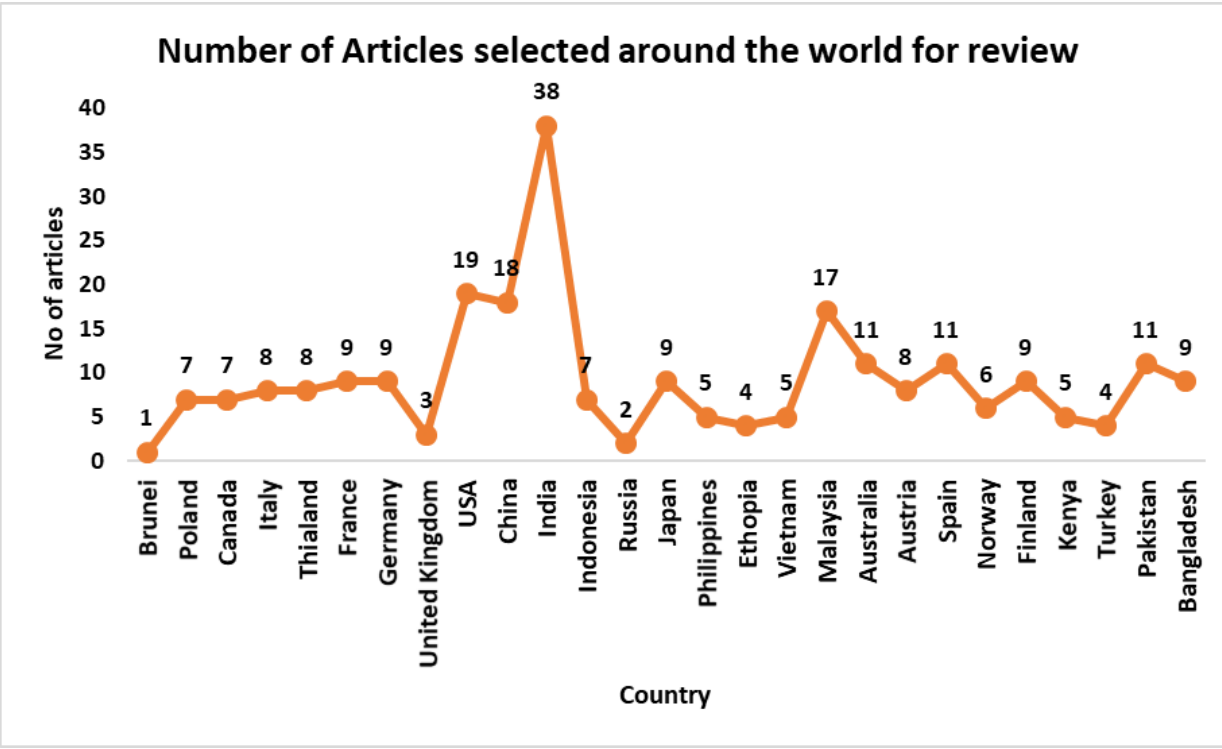

Fig. 4 Identified case studies on flood vulnerability/ Number of articles for review around the world

\subsection{Indicators for Vulnerability analysis}

Most vulnerability analysis is based on indicator selection and analysis(Behanzin et al. 2016; Diaz-Sarachaga and Jato-Espino 2020; Dottori et al. 2018; Fernandez et al. 2016b; Nasiri et al. 2019; Pricope et al. 2019b; Rufat et al. 2015b). So, it should be well circulated amongst research about different types of indicators used in the vulnerability analysis and mapping (Adger 1998; Analysis 2020; Balica et al. 2017; Barroca et al. 2006; Colburn and Seara 2011; Dickin et al. 2013; Fatemi et al. 2017; Frigerio et al. 2018; Houborg et al. 2012; Jean-Baptiste et al. 2011; Karmaoui et al. 2016; Kissi et al. 2015; Lee and Choi 2018; Nazeer and Bork 2019; Rufat et al. 2015; De Ruiter et al. 2017; Villordon 2015). Table 6 explains the process of selection of indicators in the form of a heat map, whereas Table 7, given below, represents the different types of indicators used in the vulnerability mapping around the world with their frequency of use in the selected research papers for review. Except for groundwater fluctuation, cultural heritage, flood insurance, and hydropower plant, the other indicators were mostly used by different researchers on flood mapping, which are using indicator-based analysis.

Table:6. Numbers of data sources used to assess indicators in the reviewed papers 


\begin{tabular}{|l|c|}
\hline Data Source & $\begin{array}{l}\text { Frequency of } \\
\text { publication (50) }\end{array}$ \\
\hline Expert interview & 33 \\
\hline Census & 48 \\
\hline Survey based Questionnaries & 29 \\
\hline Satellite image & 27 \\
\hline Household survey & 19 \\
\hline Field observations & 23 \\
\hline Official reports & 39 \\
\hline Previous publications & 17 \\
\hline
\end{tabular}

299 Table:7 Summary of indicators used in the different vulnerability assessment

Indicators

$\%$ of Waste land of total geographical area

No of tourist visited

Forest fire (total affected area, ha)

Urbanized area (\%) of total area.

No of HEP(hydroelectric power), All types

Outmigration, \% share of state population

(\%) of area with altitude more than $3000 \mathrm{~m}$.

$\%$ of Landslide zone area of total area

Unemployment (\%)

Cultural heritage

Population close to coastline

$\%$ growth of population near costline

$\%$ of low cost building

Population density

Disabled people

Elderly population

Children under 15

Agriculture workers

Literacy rate

Large Household size

Number of houses with poor material

Poverty Rate

Decadal growth rate

Female Population

Total no of river in the state

Total no of industries unit in the state

Human devlopment index

$\%$ of Forest cover of total geographical area(ha)

Structural measure for flood protection

Total length of approaching road linked with major district road $(\mathrm{km}$ Communication penetration rate (\%)

Area having electricity (\%)

Village connected with pucca roads (\%)

No. Of transport vehicles (registered vehicle of all types/1000 km2)

No. of hospital / lakh population

No. of flood forecasting / warning system/ Flood hazard maps Awareness about Hazard

Past Experience about Hazard

Total length of canalisation in the different part of the state $\%$ of people having flood insurance

$\%$ of open space land

Average Proximity to river of different districts in a state $(\mathrm{m})$

Average rainfall $(\mathrm{mm})$ in Monsoon season in last 25 years

Flood frequency in flash flood

Maximum rainfall ( $\mathrm{mm} /$ day)

Avg. heavy rainfall days,

Coastline length

No of cyclone

Flood duration

Total raining days

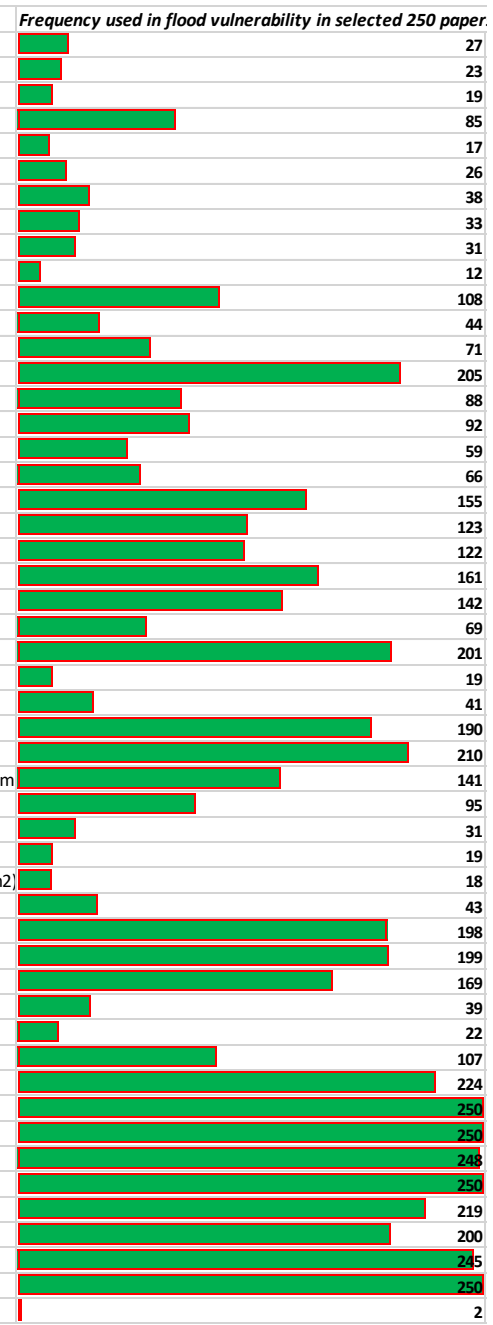




\subsection{Vulnerability assessment methods and a brief discussion on previous work} From the review of various studies, it is found that the earliest attempt to define vulnerability was made by Kates (1971), who proposed a decision model to decide how people understand hazards. The model was called vulnerability. Birkmann (2006) defined the broad and multidisciplinary view of vulnerability (Munyai et al. 2019; Pricope et al. 2019b). According to the study, indicators, and criteria used for vulnerability measurement should have a physical, economic, and social relationship with the area of interest (Sadeghi-Pouya et al. 2017; Yalcin and Akyurek 2004). Balica et al. (2012) showed the flood vulnerability in an indicator based way. This indicator-based methodology, which is used to calculate Flood Vulnerability Index (FVI) has been addressed differently for the river basin, sub-catchment, urban area and for the coastal flood (Adger 1998; Rimba et al. 2017; Villordon 2015). Atkins et al. (1998) suggested a composite vulnerability index for countries that are in the developing stage and island. Based on the available data, the integrated vulnerability index was calculated for 110 developing countries. The results suggested that small states are more vulnerable as compared to the larger ones (Dottori et al. 2018; Rezaee 2013; Shrestha et al. 2014). Moss et al. (2001) identified ten representatives for five areas of climate responsiveness (Miladan et al. 2019). These areas are arrangement sensitivity, food safety, human health consciousness, ecosystem sensitivity, and availability of water. All these representatives were assembled into different indicators like sectorial indicators, responsiveness indicators, and coping or adaptive capacity indicators. Based on these indicators, they finally constructed vulnerability resilience indicators to climate change (Dottori et al. 2018; US Energy Information Administration 2017; Yalcin et al. 2004). (Karim et al. 2016) used advanced land imager (ALI) data and other high-resolution microwave data to prepare the flood inundation map, and that was used in flood vulnerability study. In another attempt, (Diaz-Sarachaga and Jato-Espino 2020; Feloni et al. 2020; Khajehei et al. 2020; Khaki et al. 2019; Pricope et al. 2019a) used RADARSAT data, synthetic aperture radar (SAR), Sentinel-1 \& 2 to analyze flood vulnerability because of their timely image delivery. Damm et al. (2020) highlighted the possible impacts of hazard on people and their society. They also explained how risk and vulnerability are relevant to disasters (Damm et al. 2010). (Lee and Choi 2018; Len et al. 2018) used fuzzy logic for the estimation of flood vulnerability using different indicators. Their technique is useful in decision making for experts working in the field of water resource management with a multicriteria decision-making method (MCDM). Monika Blistanova et al. (2016) assess the flood vulnerability based on different criteria using GIS for the Bodva river basin found in the eastern part of Slovakia. They used different 
hydrological factors of the basin along with the geomorphological properties of the basin, like slope and soil type, etc. All these indicators are analyzed and incorporated in the GIS to classify the study region in four classes - acceptable, moderate, undesirable, and unacceptable vulnerability zone (Bereciartua 2015; Blistanova et al. 2016). Dereje Birhanua et al. (2016) asses the vulnerability of Addis Ababa due to climate change and rapid urbanization in the Akaia catchment. They used the SWAT model to obtained the peak of discharge and incorporated the peak discharge as one of the indicators. The future rainfall is predicted by using the General Circulation Models (GCM) data, and land use land cover data was prepared by using the Landsat images. The results show that there is a considerable increase in discharge due to climate change, which eventually increases the vulnerability (Ahmed et al. 2006; Birhanu et al. 2016). Per Skougaard Kaspersen et al. (2017) elaborated the multidimensional aspects of flood vulnerability considering social, economic, and hydrological components. Their analysis is based on an integrated approach for all the factors of flood vulnerability, known as the Danish Integrated Assessment System (DIAS). This DIAS is capable of evaluation of risk due to flooding from severe precipitation, and the model is applied in the city of Odense, Denmark (Kaspersen et al. 2017; Prasad et al. 2016). Jong Seok Lee et al. (2018) presented an integrated flood vulnerability index based on the recommendations of the IPCC's third assessment report. They classified the indicators of vulnerability as exposure, sensitivity, and coping capacity and formulated the integrated vulnerability assessment approach based on normalization of indicators value for the Nakdong River Watershed of the Korean Peninsula. The result of this study shows a satisfactory assessment of vulnerability due to climate change (Lee et al. 2018; Rosvoldaune et al. 2014). Hong et al. (2018b) used an integrated adaptive neuro-fuzzy inference system and GIS to spatially analyze the flood vulnerability susceptibility in Hengfeng County in Jiangxi Province, China, which is based on multicriteria approaches. The result is useful in explaining flood inundation, along with an assessment of economic losses. The summary of different methods used for the vulnerability indicator assessment is shown in Table:8. As per the table:8, authors were generally used the weight allocation and statistical analysis methods for the vulnerability indicators analysis, followed by neuro-fuzzy and fuzzy logic methods.

Table: 8 Methods used in the designated references

\begin{tabular}{|l|c|}
\hline Methods & $\begin{array}{l}\text { Frequency used in } \\
\text { different Publications }\end{array}$ \\
\hline Equal weight allocation & 23 \\
\hline
\end{tabular}




\begin{tabular}{|l|c|}
\hline Weight allocation by expert & 45 \\
\hline Weight allocation by authors & 21 \\
\hline PAC(Principal component analysis) & 14 \\
\hline PAR(Pressure and release model) & 12 \\
\hline Maximum flux analysis & 6 \\
\hline Cluster analysis & 8 \\
\hline Factor analysis & 22 \\
\hline Statistical analysis & 41 \\
\hline Fuzzy logic & 34 \\
\hline Spatial analysis & 29 \\
\hline AHP(Analytical hierarchical) & 22 \\
\hline ANP(Analytic network) & 11 \\
\hline Local Survey & 36 \\
\hline ANN(Artificial neural) & 13 \\
\hline Neuro-fuzzy & 41 \\
\hline GIS(Geographical information system) & 37 \\
\hline
\end{tabular}

\subsection{Types of flood used in the study}

The majority of work on flood vulnerability assessment were concentrated on single disaster event, i.e., flood (Blistanova et al. 2016; Earth and Information 2014; Fernandez et al. 2016a; Villordon 2015; Žurovec et al. 2017). Table 9 displays information regarding different types of flood used in flood vulnerability assessment with their rank. Here the coastal and river floods were considered most for assessment followed by urban flooding.

Table:9 Types of floods named in the studies

\section{Types of floods} named in the studies

Costal flood

Flash flood

River flood

Urban flood

Rural flood

Cloud burst

Rainstorm

\begin{tabular}{|c|c|}
$\begin{array}{l}\text { Used in no of } \\
\text { research papers }\end{array}$ & Rank \\
\hline 211 & 1 \\
154 & 4 \\
209 & 2 \\
165 & 3 \\
85 & 6 \\
29 & 7 \\
122 & 5 \\
\hline
\end{tabular}

\section{Summary and Discussion}

In earlier studies, the vulnerability has been highlighted in terms of losses caused by natural hazards. Scopus and other journal database studies showed that more than 3000 research works have empathized with the flood. The main interest of the research community was on social, environmental, and economic vulnerability. Recent papers on flood vulnerability report using new technology and statistical methods to estimate the susceptibility of place or people towards the flood. Along with hydrological factors, researchers are now considering infra and urbanrelated indicators to estimate flood vulnerability. Other than conventional methods to estimates 
the vulnerability, the new approaches like the fuzzy set, catastrophe modeling, hydraulic modeling, flood start the inspection, and multicriteria methodology was in great use for flood hazard study. Geospatial techniques, including remote sensing data and GIS, also gained attention in providing a spatial summary of flood-vulnerable regions. Keywords also recommend that the use of geospatial technologies has become more useful in flood hazard assessment and estimating flood vulnerability. The collected database showed that the significant hazardous event in India is heavy precipitation and flash flood, followed by drought. Exposure, susceptibility, and resilience have been found in key parameters for flood vulnerability. A lot of studies also carried out flood vulnerability concerning social, physical, economic, environmental, and coastal contexts. In-depth knowledge of different types of vulnerability assessment methods is helpful in the mapping of hot spot areas in different regions and the formulation of more specific information that can better minimize loss of life due to disaster. Based on the different flood vulnerability assessment techniques, it was found that the indicator-based vulnerability estimations are conventional, but they have their limitation due to complex nature-related with standardization, weighting, and aggregation methods. Indicator based approach does not calculate flood risk directly but contributes to assessing flood risk. On the other hand, fuzzy logic-based models, satellite data-based models are some distinct techniques for assessing flood risk and vulnerability. Also, the systematic review of different studies based on flood vulnerability shows that indicator-based and image analysis based studies are more relevant to present the black spot in the area to be vulnerable. The literature references known are based on a deeply related search question to bypass prejudice. The findings from different studies verify that the USA, China, Italy, and India are major contributors to disaster research.

\section{Conclusions and recommendation}

The present study attempted various methods and strategies of flood management and its vulnerability estimation since the 1980s. Based on the citation index, more than 250 articles (from 1980 to April 2020) were analyzed to get a quality based logical analysis of various vulnerability assessment methods. Selected Keywords shows a vital database and history of flood-related studies for recognizing the trend of flood vulnerability assessment around the world. Both traditional and modern methodologies are discussed, highlighting the recently used models. The findings showed that the researchers for the assessment of vulnerability mostly selected flash floods, coastal floods, and urban floods. The recently published papers (after 2017) emphasize on use of geospatial techniques, i.e., remote sensing data, GIS, hydrological models, and machine learning-based algorithms for the vulnerability assessment. Based on the review, the following conclusions have been drawn.

a The flood vulnerability assessment methods are available at different spatial scales. It would be more beneficial if it is at a micro-scale, i.e., village or sub-village level.

b The volume of papers increased significantly in the last 5 years. As such, this flood vulnerability related research domain is yet developing and assumed to keep increasing in the near future.

c The social and hydrological components were the most selected amongst the selection of the indicators. But, very few or negligible researchers consider the groundwater component as well as the economic element for the assessment of flood vulnerability. 
d Most of the researchers assessed vulnerability considering only a single kind of hazardous event, except $17 \%$ of articles considered the flood vulnerability due to multiple hazards.

e For the estimation of vulnerability, the weight allocation by the expert, statistical methods, and neuro-fuzzy methods were mostly used by different researchers. The main reason behind this is that the expert judgement is a conventional method, statistical method is common amongst other and fuzzy logic is time saving and advance techniques with more accuracy.

f Literature review, official reports, expert judgment, and census data are a popular sources of knowledge and modes for determining indicators or parameters.

Concludly, Geographic information systems, different statistical analyses, Remote Sensing, and programming languages are the major tools currently used by the different researchers for the in-depth assessment of flood vulnerability. In the present study, we tried to focus on traditional and new data sources, spatial variables, and indicators-based tools which are used to map the extent of vulnerability around the world. The principal constraints of this study were the large assortment of methodologies, type of vulnerability, followed by the references analyzed, and the selective concentration of most studies towards a distinct hazard, i.e., flood. The conclusions obtained from this study recognized many gaps to be linked by the expansion of a new integrated vulnerability assessment structure. The proposed integrated framework should be globally appropriate for all types of hazards, considering physical, social, environmental, and economic indicators of vulnerability.

\section{References}

Abebe, B. A. (2014). "Modeling the Effect of Climate and Land Use Change on the Water Resources in Northern Ethiopia: The Case of Suluh River Basin."

Adger, W. N. (1998). "Indicators of social and economic vulnerability to climate change in Vietnam." 42.

Ahmed, A. U. (2006). Bangladesh Climate Change Impacts and Vulnerability: A Synthesis. Change.

Alnaimat, A., Choy, L., and Jaafar, M. (2017). "An Assessment of Current Practices on Landslides Risk Management: A Case of Kuala Lumpur Territory." GeografiaMalaysian Journal of Society and Space, 13(2), 1-12.

Analysis, R. (2020). "Social Vulnerability Assessment for Flood."

Antwi, E. K., Boakye-Danquah, J., Barima Owusu, A., Loh, S. K., Mensah, R., Boafo, Y. A., and Apronti, P. T. (2015). "Community vulnerability assessment index for flood prone savannah agro-ecological zone: A case study of Wa West District, Ghana." Weather and Climate Extremes, 10, 56-69.

Asoka, A., Gleeson, T., Wada, Y., and Mishra, V. (2017). "Relative contribution of monsoon precipitation and pumping to changes in groundwater storage in India." Nature 
Geoscience, 10(2).

Ayala, D. D., Wang, K., Yan, Y., Smith, H., Massam, A., Filipova, V., Pereira, J. J., and Management, J. B. A. R. (2020). "Flood Vulnerability Assessment of Urban Traditional Buildings in Kuala." (April), 1-30.

Bahinipati, C. S. (1999). "Assessment of vulnerability to cyclones and floods in Odisha, India : a district-level."

Balica, S., Wright, N. G., Balica, S., and Wright, N. G. (2017). "Reducing the complexity of the flood vulnerability index Reducing the complexity of the flood vulnerability index." 7891(June).

Banyouko, A., John, N., and Odihi, O. (2017). "A Systematic Study of Disaster Risk in Brunei Darussalam and Options for Vulnerability-Based Disaster Risk Reduction.” International Journal of Disaster Risk Science, Beijing Normal University Press.

Barroca, B., Bernardara, P., Mouchel, J. M., and Hubert, G. (2006). "Indicators for identification of urban flooding vulnerability." 553-561.

Basheer Ahammed, K. K., and Pandey, A. C. (2019). "Coastal Social Vulnerability and Risk Analysis for Cyclone Hazard Along the Andhra Pradesh, East Coast of India." KN Journal of Cartography and Geographic Information, Springer International Publishing, 69(4), 285-303.

Beerens, R. J. J., Tehler, H., and Pelzer, B. (2020). "How can we make disaster management evaluations more useful? An empirical study of Dutch exercise evaluations." International Journal of Disaster Risk Science, Beijing Normal University Press.

Behanzin, D. I., Thiel, M., Szarzynski, J., and Boko, M. (2016). "GIS-Based Mapping of Flood Vulnerability and Risk in the Bénin Niger River Valley.” International Journal of Geomatics and Geosciences, 6(3), 1653-1669.

BELL, F. G. (1980). "River Engineering.” Engineering Geology and Geotechnics, 361-394.

Bereciartua, P. (2015). “Bereciartua_paper.” A conceptual framework for reducing water vulnerability to extreme events by risk transferring schemes: elements of a case study in the Pampas system, Argentina.

Bhadra, A., Bandyopadhyay, A., Hodam, S., Yimchungru, C. Y., and Debbarma, R. (2009). "Assessment of Vulnerability of Arunachal Pradesh ( India ) to Floods."

Bhatt, D., and Mall, R. K. (2015). "Surface Water Resources, Climate Change and Simulation Modeling.” Aquatic Procedia, Elsevier B.V., 4(Icwrcoe), 730-738.

Birhanu, D., Kim, H., Jang, C., and Park, S. (2016). "Flood Risk and Vulnerability of Addis Ababa City Due to Climate Change and Urbanization." Procedia Engineering, Elsevier B.V., 154, 696-702.

Blaikie, P., and Cannon, T. (2006). "Social Vulnerability."

Blistanova, M., Zele, M., Blistan, P., and Ferencz, V. (2016). “Assessment of flood vulnerability in Bodva river basin, Slovakia." 21(1), 19-28.

Briguglio, L. (2004). “ECONOMIC VULNERABILITY AND RESILIENCE : CONCEPTS AND MEASUREMENTS." (March). 
Brown, M. K. (2012). "LANDSLIDE DETECTION AND SUSCEPTIBILITY MAPPING USING LIDAR AND.” (December).

Cardona, O. (2012). "Determinants of Risk : Exposure and Vulnerability Coordinating Lead Authors : Lead Authors : Review Editors : Contributing." Managing the Risks of Extreme Events and Disasters to Advance Climate Change Adaptation - A Special Report of Working Groups I and II of the Intergovernmental Panel on Climate Change (IPCC), 65-108.

Chakraborty, A., and Joshi, P. K. (2017). "Mapping disaster vulnerability in India using analytical hierarchy process." Taylor \& Francis, 5705(November).

Chanawongse. 2011. Pengaruh kompetensi, indepedensi, workload dan spesialisasi auditor terhadap kualitas audit. pp: 1-2. (2014). “No 主観的健康感を中心とした在宅高齢者 における 健康関連指標に関する共分散構造分析Title.” 運輸と経済, 2014(June), 12 .

Chinnasamy, P., Maheshwari, B., and Prathapar, S. (2015). "Understanding groundwater storage changes and recharge in Rajasthan, India through remote sensing." Water (Switzerland), 7(10), 5547-5565.

Colburn, L., and Seara, T. (2011). "Resilience, vulnerability, adaptive capacity, and social capital." $1-14$.

Commission, C. W., Forecast, F., and Directorate, M. (2010). "Flood Forecasting and Warning Government of India Flood Forecast Monitoring Directorate."

Coninx, I., and Bachus, K. (2007). "Integrating Social Vulnerability to Floods in a Climate Change Context." Proc. int. conf. on adaptive and integrated water management, coping with complexity and uncertainty, 30.

Costa, H., Dias, L., Grosso, N., and Garrett, P. (2014). "National flood vulnerability index." 12.

COSTA, R. N., and MACHADO, C. J. S. (2017). "Social and Environmental Vulnerability in Environmental Education Practiced Within the Federal Licensing in Maca? (Rio De Janeiro, Brazil)." Ambiente \& Sociedade, 20(1), 127-146.

D/iya, S. G., Gasim, M. B., Toriman, M. E., and Abdullahi, M. G. (2014). "Floods in Malaysia: Historical Reviews, Causes, Effects and Mtigations Approach.” International Journal of Interdisciplinary Research and Innovations, 2(4), 59-65.

Damm, M., Fekete, A., and Bogardi, J. (2010). "Intersectoral vulnerability indices as tools for framing risk mitigation measures and spatial planning." Conference Proc. Hydro ....

Dhami, B. S., and Pandey, A. (2013). "Comparative Review of Recently Developed Hydrologic Models.” Journal of Indian Water Resources Society, 33, 34-42.

Diaz-Sarachaga, J. M., and Jato-Espino, D. (2020). "Analysis of vulnerability assessment frameworks and methodologies in urban areas." Natural Hazards, 100(1), 437-457.

Dickin, S. K., Schuster-Wallace, C. J., and Elliott, S. J. (2013). "Developing a Vulnerability Mapping Methodology: Applying the Water-Associated Disease Index to Dengue in Malaysia." PLoS ONE, 8(5).

Dimri, A. P., Chevuturi, A., Niyogi, D., Thayyen, R. J., Ray, K., Tripathi, S. N., Pandey, A. 
K., and Mohanty, U. C. (2017). "Cloudbursts in Indian Himalayas: A review.” EarthScience Reviews, 168, 1-23.

Dottori, F., Martina, M. L. V., and Figueiredo, R. (2018). "A methodology for flood susceptibility and vulnerability analysis in complex flood scenarios." Journal of Flood Risk Management, 11, S632-S645.

Earth, I., and Information, S. (2014). "DESIGN AND USE OF COMPOSITE INDICES IN ASSESSMENTS OF CLIMATE CHANGE VULNERABILITY AND RESILIENCE.” (July).

Fatemi, F., Ardalan, A., Aguirre, B., Mansouri, N., and Mohammadfam, I. (2017). "Social vulnerability indicators in disasters: Findings from a systematic review." International Journal of Disaster Risk Reduction, Elsevier Ltd, 22(September 2016), 219-227.

Feloni, E., Mousadis, I., and Baltas, E. (2020). "Flood vulnerability assessment using a GISbased multi-criteria approach-The case of Attica region." Journal of Flood Risk Management, 13(S1), 1-15.

Fernandez, P., Mourato, S., and Moreira, M. (2016a). "Social vulnerability assessment of flood risk using GIS-based multicriteria decision analysis. A case study of Vila Nova de Gaia." Geomatics, Natural Hazards and Risk, 7(4).

Fernandez, P., Mourato, S., Moreira, M., and Pereira, L. (2016b). "A new approach for computing a flood vulnerability index using cluster analysis." Physics and Chemistry of the Earth, Elsevier Ltd, 94, 47-55.

Flanagan, B. E., Gregory, E. W., Hallisey, E. J., Heitgerd, J. L., and Lewis, B. (2011). “A Social Vulnerability Index for Disaster Management." Journal of Homeland Security and Emergency Management, 8(1).

Frigerio, I., Carnelli, F., Cabinio, M., and De Amicis, M. (2018). "Spatiotemporal Pattern of Social Vulnerability in Italy." International Journal of Disaster Risk Science, Beijing Normal University Press, 9(2), 249-262.

Gebreyes, M., and Theodory, T. (2018). "Understanding social vulnerability to climate change using a 'riskscapes' lens: Case studies from Ethiopia and Tanzania." Erdkunde, 72(2), 163-164.

Ghani, A. A., Chang, C. K., Leow, C. S., and Zakaria, N. A. (2012). "Sungai Pahang digital flood mapping: 2007 flood.” International Journal of River Basin Management, 10(2), $139-148$.

Godah, W., Szelachowska, M., and Krynski, J. (2017). "On the analysis of temporal geoid height variations obtained from GRACE-based GGMs over the area of Poland." Acta Geophysica, 65(4).

Houborg, R., Rodell, M., Li, B., Reichle, R., and Zaitchik, B. F. (2012). "Drought indicators based on model-assimilated Gravity Recovery and Climate Experiment (GRACE) terrestrial water storage observations." Water Resources Research, 48(7).

Huang, Y., Zou, Y., Huang, G., Maqsood, I., and Chakma, A. (2005). "Flood vulnerability to climate change through hydrological modeling: A case study of the swift current creek watershed in western canada." Water International, 30(1), 31-39.

Iqbal, N., Hossain, F., Lee, H., and Akhter, G. (2017). “Integrated groundwater resource 
management in Indus Basin using satellite gravimetry and physical modeling tools." Environmental Monitoring and Assessment, Environmental Monitoring and Assessment, 189(3), 1-16.

Jean-Baptiste, N., Kuhlicke, C., Kunath, A., and Kabisch, S. (2011). "Review and evaluation of existing vulnerability indicators in order to obtain an appropriate set of indicators for assessing climate related vulnerability." CLimate change and Urban Vulnerability in Africa, Helmholtz Centre for Environmental Research-UFZ, 1-180.

Jha, R. K., Gundimeda, H., and Prakash, A. (2016). "4 th International Climate Change Adaptation Conference, Rotterdam An assessment of relative vulnerability to floods by using data envelopment By Ongoing Ph . D Project Districts of Bihar Source : District boundaries digitized on SoI Toposheet by Authors."

Kaly, U. L., Pratt, C., and Mitchell, J. (2005). "Building Resilience in SIDS. The Environmental Vulnerability Index." 1-12.

Kannan, S., and Ghosh, S. (2011). "Prediction of daily rainfall state in a river basin using statistical downscaling from GCM output." Stochastic Environmental Research and Risk Assessment, 25(4), 457-474.

Karim, F., Petheram, C., Marvanek, S., Ticehurst, C., Wallace, J., and Hasan, M. (2016). "Impact of climate change on floodplain inundation and hydrological connectivity between wetlands and rivers in a tropical river catchment." Hydrological Processes, 30(10), 1574-1593.

Karmaoui, A., Balica, S. F., and Messouli, M. (2016). "Analysis of applicability of flood vulnerability index in Pre-Saharan region, a pilot study to assess flood in Southern Morocco." Natural Hazards and Earth System Sciences Discussions, 2(April), 1-24.

Kaspersen, P. S., and Halsn, K. (2017). "Integrated climate change risk assessment : A practical application for urban flooding during extreme precipitation." 6, 55-64.

Khajehei, S., Ahmadalipour, A., Shao, W., and Moradkhani, H. (2020). "A Place-based Assessment of Flash Flood Hazard and Vulnerability in the Contiguous United States." Scientific Reports, 10(1), 1-12.

Khaki, M., Hoteit, I., Kuhn, M., Forootan, E., and Awange, J. (2019). "Science of the Total Environment Assessing data assimilation frameworks for using multi-mission satellite products in a hydrological context." Science of the Total Environment, Elsevier B.V., 647, 1031-1043.

Kissi, A. E., Abbey, G. A., Agboka, K., and Egbendewe, A. (2015). "Quantitative Assessment of Vulnerability to Flood Hazards in Downstream Area of Mono Basin , South-Eastern Togo : Yoto District.” Journal of Geographic Information System, (December), 607-619.

Kulatunga, U., Pathirage, C., Thayaparan, M., and Sulaiman, N. (2016). "Vulnerability assessment for climate - induced disasters in Malaysia."

Kumar, D., and Kumar Bhattacharjya, R. (2020a). "Study of Integrated Social Vulnerability Index SoVI int of Hilly Region of Uttarakhand, India." 24(1), 105-122.

Kumar, D., and Kumar Bhattacharjya, R. (2020b). "Estimation of Integrated Flood Vulnerability Index for the Hilly Region of Uttarakhand, India." ASCE, 24(1), 105-122. 
Learning, B. (n.d.). "Chapter 2 Hazards, Vulnerability , and Disaster Risk."

Lee, J. S., and Choi, H. Il. (2018). "Comparison of flood vulnerability assessments to climate change by construction frameworks for a composite indicator." Sustainability (Switzerland), 10(3).

Len, N. L. S., Bolong, N., Roslee, R., Tongkul, F., bin Mirasa, A. K., and Ayog, J. L. (2018). "Flood vulnerability index for critical infrastructure towards flood risk management." ASM Science Journal, 11(Special Issue 3), 134-146.

Li, G., and Matthew, R. G. S. (1990). "New Approach for Optimization of Urban Drainage Systems." Journal of Environmental Engineering, American Society of Civil Engineers, 116(5), 927-944.

Line, B. (1999). "Earthquake and Physical and Social Vulnerability Assessment for Settlements : Case Study Avcilar District."

Liu, J., and Shi, Z. wu. (2017). "Quantifying land-use change impacts on the dynamic evolution of flood vulnerability.” Land Use Policy, Elsevier, 65(August 2016), 198-210.

Lujala, P., Lein, H., and Rosvoldaune, R. (2014). "Quantifying vulnerability to flooding induced by climate change: The case of Verdal, Norway.” Norsk Geografisk Tidsskrift, Taylor \& Francis, 68(1), 34-49.

Mahmood, R., and Babel, M. S. (2014). "Future changes in extreme temperature events using the statistical downscaling model (SDSM) in the trans-boundary region of the Jhelum river basin." Weather and Climate Extremes, Elsevier, 5(1), 56-66.

Mahmood, R., and Jia, S. (2016). "Assessment of Impacts of Climate Change on the Water Resources of the Transboundary Jhelum River Basin of Pakistan and India." Water, 8(6), 246.

Mahmood, R., Jia, S., and Babel, M. S. (2016). "Potential Impacts of Climate Change on Water Resources in British Columbia Communities." Mdpi, (26), 1-24.

Management, H. D. (n.d.). "CONCEPTUAL MODEL : CONCEPTUAL MODEL.” 17(Suppl 3), 56-68.

Management, N. I. of D. (2014). Uttarakhand Disaster 2013.

Martini, F., and Loat, R. (2007). "Handbook on good practices for flood mapping in Europe." European exchange circle on flood mapping, 60.

Miladan, N., Ariani, F., Pertiwi, S. N. I., Setiawan, R., and Handayani, K. N. (2019). "Land Use Vulnerability towards the Flood Risk in Surakarta City." MATEC Web of Conferences, 280, 01011.

Mishra, N., Khare, D., Shukla, R., and Singh, L. (2013). "A Study of Temperature Variation in Upper Ganga Canal Command India." 1(3), 45-51.

Mujumdar, P. P. (2011). "Implications of climate change for sustainable water resources management in India." India Infrastructure Report 2011, 18-28.

Munyai, R. B., Musyoki, A., and Nethengwe, N. S. (2019). "An assessment of flood vulnerability and adaptation: A case study of Hamutsha-Muungamunwe village, Makhado municipality.” Jàmbá: Journal of Disaster Risk Studies, 11(2), 1-8. 
Nasiri, H., Yusof, M. J. M., Ali, T. A. M., and Hussein, M. K. B. (2019). "District flood vulnerability index: urban decision-making tool." International Journal of Environmental Science and Technology, Springer Berlin Heidelberg, 16(5), 2249-2258.

National Institute of Disaster Management. (2012). "India Disaster Report - 2011.” 1-85.

Nazeer, M., and Bork, H. R. (2019). "Flood vulnerability assessment through different methodological approaches in the context of North-West Khyber Pakhtunkhwa, Pakistan." Sustainability (Switzerland), 11(23).

Nisha, and Punia, M. (2014). "Socio-economic vulnerability and sustainable development in context of development vs. conservation debate: A study of bhagirathi basin, uttarakhand, India." International Archives of the Photogrammetry, Remote Sensing and Spatial Information Sciences - ISPRS Archives, XL-8(1), 77-84.

Nojang, E. N., and Jensen, J. (2020). "Conceptualizing Individual and Household Disaster Preparedness: The Perspective from Cameroon.” International Journal of Disaster Risk Science, Beijing Normal University Press, 11(3), 333-346.

Ojha, C. S. P., Goyal, M. K., and Adeloye, A. J. (2010). "Downscaling of Precipitation for Lake Catchment in Arid Region in India using Linear Multiple Regression and Neural Networks.” 122-136.

Ologunorisa, T. E. (2004). "An assessment of flood vulnerability zones in the Niger Delta, Nigeria." International Journal of Environmental Studies, 61(1), 31-38.

Pankaj, G. (2018). "Flash Flood and its Mitigation : A Case Study of Almora, Uttarakhand, India Journal of Environmental Hazards." 1(1), 1-7.

Pant, V., and Pande, P. R. K. (2012). "Disaster Risk Analysis ( DRA ): Case Studies from Pithoragarh." 1(6), 24-26.

Park, J., Kang, M. S., and Song, I. (2015). "Assessment of Flood Vulnerability Based on CMIP5 Climate Projections in South Korea." Journal of the American Water Resources Association, 51(3), 859-876.

Parth Sarthi, P., Ghosh, S., and Kumar, P. (2015). "Possible future projection of Indian Summer Monsoon Rainfall (ISMR) with the evaluation of model performance in Coupled Model Inter-comparison Project Phase 5 (CMIP5)." Global and Planetary Change, Elsevier B.V., 129, 92-106.

Peters, L. E. R., and Kelman, I. (2020). "Critiquing and Joining Intersections of Disaster, Conflict, and Peace Research.” International Journal of Disaster Risk Science, Beijing Normal University Press.

Pichuka, S., Prasad R, R., Maity, R., and Kunstmann, H. (2017a). "Development of a method to identify change in the pattern of extreme streamflow events in future climate: Application on the Bhadra reservoir inflow in India." Journal of Hydrology: Regional Studies, Elsevier B.V., 9, 236-246.

Pichuka, S., Prasad R, R., Maity, R., and Kunstmann, H. (2017b). "Development of a method to identify change in the pattern of extreme streamflow events in future climate: Application on the Bhadra reservoir inflow in India." Journal of Hydrology: Regional Studies, Elsevier B.V., 9, 236-246.

Prasad, N. N. R., and Narayanan, P. (2016). "Vulnerability assessment of flood-affected 
locations of Bangalore by using multi-criteria evaluation." Annals of GIS, Taylor \& Francis, 22(2), 151-162.

Pricope, N. G., Halls, J. N., Rosul, L. M., and Hidalgo, C. (2019a). "Residential flood vulnerability along the developed North Carolina, USA coast: High resolution social and physical data for decision support." Data in Brief, The Author(s), 24, 103975.

Pricope, N. G., Halls, J. N., Rosul, L. M., and Hidalgo, C. (2019b). "Residential flood vulnerability along the developed North Carolina, USA coast: High resolution social and physical data for decision support." Data in Brief, The Author(s), 24, 103975.

Rahman, H. A. (2017). "Landslides Disaster in Malaysia: an Overview Article in Health \& the." Environment Journal, (November).

Rana, N., Singh, S., Sundriyal, Y. P., and Juyal, N. (2013). "Recent and past floods in the alaknanda valley: Causes and consequences." Current Science, 105(9), 1209-1212.

Rezaee, L. Z. (2013). "MAPPING FLOOD VULNERABILITIES.” (September).

Rimba, A. B., Setiawati, M. D., Sambah, A. B., and Miura, F. (2017). "Physical Flood Vulnerability Mapping Applying Geospatial Techniques in Okazaki City , Aichi."

Rodrigo, S. K. A. (2016). "Working for welfare: Inequality and shared vulnerability among the Malaysian middle classes." Malaysian Journal of Economic Studies, 53(1), 9-31.

Rufat, S., Tate, E., Burton, C. G., and Maroof, A. S. (2015a). "Social vulnerability to floods: Review of case studies and implications for measurement." International Journal of Disaster Risk Reduction, 14.

Rufat, S., Tate, E., Burton, C. G., and Maroof, A. S. (2015b). "Social vulnerability to floods: Review of case studies and implications for measurement." International Journal of Disaster Risk Reduction, Elsevier Ltd, 14, 470-486.

De Ruiter, M. C., Ward, P. J., Daniell, J. E., and Aerts, J. C. J. H. (2017). "Review Article: A comparison of flood and earthquake vulnerability assessment indicators." Natural Hazards and Earth System Sciences, 17(7), 1231-1251.

Sadeghi-Pouya, A., Nouri, J., Mansouri, N., and Kia-Lashaki, A. (2017). “An indexing approach to assess flood vulnerability in the western coastal cities of Mazandaran, Iran." International Journal of Disaster Risk Reduction, Elsevier Ltd, 22(October 2016), 304316.

Sahana, M. (n.d.). "Ecological and Socio-economic Vulnerability Assessment to." 1-25.

Sangati, M. (2009). "Flash Flood Analysis and Modelling in Mountain Regions." 145 pages.

Sapkota, P., Bharati, L., Gurung, P., Kaushal, N., and Smakhtin, V. (2013). "Environmentally sustainable management of water demands under changing climate conditions in the upper ganges basin, India.” Hydrological Processes, 27(15), 2197-2208.

Sebald, C. (2010). "Towards an Integrated Flood Vulnerability Index - A Flood Vulnerability Assessment." Geo-Information Science and Earth Observation for Environmental Modelling and Management, MSc(March), 87.

Seekao, C., and Pharino, C. (2016). "Key factors affecting the flood vulnerability and adaptation of the shrimp farming sector in Thailand." International Journal of Disaster Risk Reduction, Elsevier, 17, 161-172. 
Shekhar, M. S., Pattanayak, S., and Mohanty, U. C. (2015). "A study on the heavy rainfall event around Kedarnath area (Uttarakhand ) on 16 June 2013.” (7), 1531-1544.

Shrestha, A. B. (2008). "Resource Manual on Flash Flood Risk Management Module 2: Nonstructural Measures." 87.

Shrestha, S., Khatiwada, M., Babel, M. S., and Parajuli, K. (2014). "Impact of Climate Change on River Flow and Hydropower Production in Kulekhani Hydropower Project of Nepal." Environmental Processes, 1(3), 231-250.

Shukla, R., Khare, D., and Deo, R. (2016). "Statistical downscaling of climate change scenarios of rainfall and temperature over Indira Sagar canal command area in Madhya Pradesh, India." Proceedings - 2015 IEEE 14th International Conference on Machine Learning and Applications, ICMLA 2015, 313-317.

Singh, S. R., Eghdami, M. R., and Singh, S. (2014). "The Concept of Social Vulnerability : A Review from Disasters Perspectives." International Journal of Interdisciplinary and Multidisciplinary Studies, 1(6), 71-82.

Storch, H. Von, and Zwiers, F. W. (1999). "Statistical Analysis in Climate Research." Journal of the American Statistical Association, 95, 1375.

Studies, E., and Tsakiris, G. P. (n.d.). "Water Resources Management Study of Integrated Social Vulnerability Index ( SoVIint ) of Uttarakhand, India Indian Institute of Technology Guwahati Study of Integrated Social Vulnerability Index ( SoVI int ) of Uttarakhand , India Abstract :"

Tan, M. L., Prasanna, R., Stock, K., Doyle, E. E. H., Leonard, G., and Johnston, D. (2020). "Modified Usability Framework for Disaster Apps: A Qualitative Thematic Analysis of User Reviews." International Journal of Disaster Risk Science, Beijing Normal University Press.

Temperatures, S. (2011). "Flood vulnerability in an urban context has been widely examined and a wide range of indicators have been suggested by researchers from various perspectives . Different aspects of vulnerability from social to physical have been considered . Table 6 - 2 pr." 195-200.

Teng, J., Jakeman, A. J., Vaze, J., Croke, B. F. W., Dutta, D., and Kim, S. (2017). "Flood inundation modelling: A review of methods, recent advances and uncertainty analysis." Environmental Modelling and Software, Elsevier Ltd, 90, 201-216.

US Energy Information Administration. (2017). "Flood Vulnerability Assessment Map." (January 2008).

Villordon, M. B. B. (2015). "Community-based flood vulnerability index for urban flooding: understanding social vulnerabilities and risks Docteur en Sciences." Université Nice Sophia Antipolis, 552.

Whitehead, P. G., Sarkar, S., Jin, L., Futter, M. N., Caesar, J., Barbour, E., Butterfield, D., Sinha, R., Nicholls, R., Hutton, C., and Leckie, H. D. (2015). "Dynamic modeling of the Ganga river system: impacts of future climate and socio-economic change on flows and nitrogen fluxes in India and Bangladesh." Environmental Science-Processes \& Impacts, 17(6), 1082-1097.

Wijaya, A. P., and Hong, J. H. (2018). "Quantitative assessment of social vulnerability for landslide disaster risk reduction using gis approach (case study: Cilacap regency, 
province of central Java, Indonesia)." International Archives of the Photogrammetry, Remote Sensing and Spatial Information Sciences - ISPRS Archives, 42(4), 77-85.

804

805

806

807

808

809

810

811

812

813

814

815

816

817

818

Xiao, L., Wang, J., Zhu, Y., and Zhang, J. (2020). "Quantitative Risk Analysis of a RainfallInduced Complex Landslide in Wanzhou County, Three Gorges Reservoir, China." International Journal of Disaster Risk Science, Beijing Normal University Press, 11(3), $347-363$.

Yalcin, G., and Akyurek, Z. (2004). "Analysing flood vulnerable areas with multicriteria evaluation." Geo-Imagery Bridging Continents, XXth ISPRS Congress, 12-23.

Yan, X., and Li, X. (2016). "Evaluation on social vulnerability to natural disasters." Anthropologist, 24(2), 570-580.

Žurovec, O., Čadro, S., and Sitaula, B. (2017). "Quantitative Assessment of Vulnerability to Climate Change in Rural Municipalities of Bosnia and Herzegovina." Sustainability, 9(7), 1208. 